\title{
Exploring the Relative Effectiveness of Emotional, Rational, and Combination Advertising Appeals on Sport Consumer Behavior
}

\section{Seunghwan Lee and Bob Heere}

Seunghwan Lee, PhD, is an assistant professor in the College of Physical Education at Kookmin University, South Korea. His research interests include sport team emotion, branding in sport, and consumer experience issues.

Bob Heere, PhD, is an associate professor in the Department of Sport and Entertainment Management at University of South Carolina. His research interests include identity, branding, brand community, brand personality, and scale development.

\begin{abstract}
The purpose of this study was to empirically examine the relative effectiveness of emotional advertising over rational advertising and combination advertising on sport consumer behavior. To achieve this purpose, a 2 (emotion) $\times 2$ (cognition) incomplete factorial design was employed with three experimental conditions (emotional, rational, and combination ad). A total of 324 participants with 108 participants in each of the three advertisements were recruited from a large public university in the United States. To test the relative effectiveness of the three advertising appeals on consumer behavior, multiple ANCOVAs with three experimental conditions (emotional ad: high emotion/low cognition vs. rational ad: low emotion/high cognition vs. combination ad: high emotion/high cognition) were conducted for the four dependent variables: attitudes toward the ads, brand attitudes, purchase intention, and merchandise consumption. Fanship was included as a covariate in order to control for a pre-existing characteristic that affects sport consumer behavior. The results suggested that emotional advertising led to a higher attitude toward the ad, brand attitude, purchase intention, and merchandise consumption than both rational and combination advertising. It was also revealed that combination advertising led to a higher attitude toward the ad than rational advertising. The findings will provide a deeper understanding of how to develop and design sport advertising as a vital component of overall marketing mix.
\end{abstract}

Keywords: emotional advertising, rational advertising, symbolic consumptions, sport consumer behavior

\section{Introduction}

Advertising has become one of the most vital commercial activities in the contemporary business environment (Um, 2008). Firms assign a large portion of their advertising budgets to create and maintain brand awareness and brand loyalty in the hopes of making consumers repeatedly purchase their products (Kotler \& Armstrong, 2009). There is greater inducement to consumers' new or repeat purchases when they are exposed to effective advertising campaigns (Yoo \& MacInnis, 2005). It is not surprising, therefore, that sport teams have spent significant resources towards their advertisements to affect consumer behavior (Shank \& Lyberger, 2015). For example, within the collegiate sport setting, total operating expenses, including advertising costs, for the 50 public schools in the Power Five conferences rose by $\$ 332$ million in 2015 (Brady, Berkowitz, \& Upton, 2016).

In order to understand how to create effective advertising, a number of advertising scholars have primarily relied on a dichotomy approach: 1) An emotional appeal and 2) A rational appeal (e.g., Aaker \& Norris, 1982; Cornelis, Adams, \& Cauberghe, 2012; Golden \& Johnson, 1983; Lwin, Phau, Huang, \& Lim, 2014; Page, Thorson, \& Heide, 1990; Panda, Panda, \& Mishra, 2013). Emotional appeals are meant to activate the feelings fans have towards their favorite sport teams, through the image of a historic win, images 
of fans celebrating, or by highlighting emotions that they associate with the teams (e.g. excitement, pride, etc.). Rationale appeals are meant to provide fans with information about the teams, such as location and dates of games, or information on a new head coach or star player. While the studies on the dichotomy of targeting emotions or cognition in advertising showed inconsistent and conflicting findings about which advertising appeal is more effective, the framework has been acknowledged to contribute strongly to our understanding of advertising appeals on consumer behavior.

Despite the importance of advertising appeals in predicting consumer behavior, little attention has been focused on the effect of such advertising appeals on sport consumer behavior in the context of spectator sport. More specifically, no studies within sport marketing have been conducted that compared the two different approaches to advertising within the field of sport management. Accordingly, how sport fans respond to either emotional or rational advertising remains largely unexplored. However, understanding types of advertising appeals and their relative impacts on consumer behavior are important in the realm of spectator sport because it provides sport marketers with some insight into how to create and maintain brand (sport team) awareness and loyalty and fans' attendance at sporting events.

For this, by taking a contingency approach suggesting that the relative effectiveness of rational and emotional advertising depends on the type of product (Holbrook \& O’Shaughnessy, 1984; Johar \& Sirgy, 1991), this study attempts to specify a "boundary condition" (i.e., the hedonic, experiential, and symbolic nature of sport team consumption) where emotional advertising might be more effective than rational advertising (Armstrong, 2007; Mowen, 1995). Based on the results of this study identifying which advertising method is more effective, sport marketers can use the more effective advertising appeal as a key component of overall marketing mix to leverage consumer behavior. To that end, in this study, the authors will examine how consumers respond to different forms of advertising and compare the effectiveness of types of advertising appeals on consumer behavior within a sport setting.

\section{Theoretical Background}

\section{Types of Adverting Appeals}

The emotional/rational framework has been studied extensively within the advertising literature. In general, advertising appeals tend to be classified as either emotional or rational, based on messages in the given context although these two types in other contexts are used interchangeably as transformational/ informational appeals (Belch \& Belch, 2015). The basic distinction between emotional and rational appeals stems from Copeland's (1924) proposition that individuals purchase products for either rational or emotional reasons. Rational appeals originate from the traditional information processing models of decision-making where the consumer is considered to make logical and rational decisions based on a products' utility (Bettman, 1979; Sheth, 1973). The rational appeals "relate to the audience's self-interest. They show that the product will produce the desired benefits. Examples are messages showing a product's quality, economy, value, or performance" (Kotler \& Armstrong, 2009, p. 411). Consequently, such appeals are designed to change the advertising viewer's beliefs about the advertised brand and rely on their persuasive power of reasons about brand attributes (Aaker, Batra, \& Myers, 1992).

In contrast, emotional appeals stem from the emotional, experiential side of consumption (Holbrook \& Hirschman, 1982). Kotler and Armstrong (2009) claim that emotional appeals attempt to provoke either negative or positive emotions that can motivate a purchase. Negative emotional appeals include fear, guilt, and shame appeals that coerce consumers to initiate certain behavior or eliminate certain behavioral practices from their routine. Advertisers also employ positive emotional appeals such as love, humor, pride and joy. Emotional appeals are often strategically utilized to make the consumer feel good about the product (Calder \& Gruder, 1989) and make a brand liked or friendly (Batra \& Ray, 1985).

Advertising scholars have explored the effectiveness of the two approaches, and have produced inconsistent and conflicting results in regards to which approach is more effective (Um, 2008). Aaker and Norris (1982) found that informational appeals resulted in higher effectiveness ratings than emotional appeals on the basis of their study of 524 TV commercials. Specifically, the authors maintained that the advertising attitude created by the rational appeal was better than that by the emotional appeal because the rational appeal appears to provide information explicitly and directly related to a product, which attracts consumers' attention more easily and produces a better advertising attitude. Golden and Johnson (1983) tested the effectiveness of two types of appeals (thinking vs. feeling) for four products (airlines, soft drinks, petroleum, and hair care) and revealed that thinking ads were perceived as relatively more likeable and elicited higher purchase intentions than feeling ads by providing more information. Recently, Cornelis et al. (2012) found that 
rational advertising is better at predicting attitude towards both the ad and the brand.

In contrast, Goldberg and Gorn (1987) found that emotional commercials led to generally more positive reactions than informational commercials. That is, respondents felt happier when watching the emotional commercials, evaluated them as more effective, and reported a higher purchase intention. Page et al. (1990) also reported that emotional ads might be more effective and memorable than rational ads. They claimed that ad-induced emotions strengthen the memory trace for the ad, which enhances the likelihood that the brand name will be recalled. More recently, Panda et al. (2013) argued that emotional advertising is more useful because it draws attention to and fosters an emotional bonding with a brand. Specifically, the authors found that advertising that evokes positive emotions like cheerfulness, happiness, interest and lack of irritation are associated with higher advertising and brand recognition. Gopinath, Thomas, and Krishnamurthi (2014) also revealed that emotional advertising has a stronger impact on sales than rational advertising, due to its slower wear-out phenomenon compared with rational advertising.

In terms of content analyses in services advertising, the findings also are contradictory. LaBand, Pickett, and Grove (1992) and Zinkhan, Johnson, and Zinkhan (1992) proposed that for services advertisements, more informational appeals are used. On the contrary, Abernethy and Butler (1992) and Cutler and Javalgi (1993) reported more emotional appeals are used in services ads. Recently, Lwin et al. (2014) revealed that emotional advertising is more effective in gaining and retaining potential customers' interest and attention in the context of boutique hotels.

Furthermore, explanations on why more emotional or informational appeals are used in services ads have been conflicting. LaBand et al. (1992) attributed the use of informational appeals to the intangibility of services. That is, the provision of more specific, concrete information may reduce the higher levels of perceived risk that are associated with the purchase of services due to their intangibility and heterogeneity or variability. In contrast, Cutler and Javalgi (1993) and Zinkhan et al. (1992) attributed the use of emotional appeals to intangibility, but suggested that emotional appeals can be effective by creating meaningful association with the intangible service.

Aaker et al. (1992), Golden and Johnson (1983), Sewall and Sarel (1986), and Shavitt $(1990,1992)$ all suggested that a strict dichotomy of rational and emotional appeals might not provide an accurate portrayal of advertising effectiveness and that there are interactions between appeal types and product categories. More specifically, Holbrook and O'Shaughnessy (1984) advocated a contingency approach that the relative effectiveness of rational and emotional advertising depends on (or matches) the type of product. According to this scheme, rational advertising should be used to construct recall for thinking products such as automobiles and furniture while emotional advertising is more appropriate to encourage attitude change toward feeling products such as jewelry and fashion merchandise (Holbrook \& O'Shaughnessy, 1984). Other works have shown that rational advertising is more effective for tangible and utilitarian products whereas emotional advertising is more effective for intangible, experiential or hedonic products (Huertas \& Campomar, 2009; Lwin \& Phau, 2013). Accordingly, these works are in line with Holbrook and O'Shaughnessy's (1984) contingency approach on the relative effectiveness of advertising appeals. With slightly different terminology, Johar and Sirgy (1991) argued that value-expressive (similar to emotional or feeling) advertising is more suitable for value-expressive products, whereas utilitarian (similar to rational or thinking) advertising is more suitable for utilitarian products. More recently, Zhang, Sun, Liu, and Knight (2014) found that emotional advertising resulted in higher purchase intention in the experience services (e.g., restaurants, airlines) whereas rational advertising produced a higher purchase intention in the credence services (e.g., dentist, hospital). Considering that sport consumption is more closely related to experience services than to credence service, Zhang et al.'s (2014) work provides a potential point that emotional advertising might be more effective in spectator sport than rational advertising.

It has been widely recognized that such value-expressive (symbolic) benefit and value suggested by Johar and Sirgy (1991) are overwhelmingly important determinants in sport consumption, particularly spectator sport (Hirschman \& Holbrook, 1982; Hopkinson \& Pujari, 1999). According to Mowen (1995), value-expressive products that consumers use to communicate themselves to others as symbols must have three characteristics: (1) they should have visibility in use such that the consumption is easily apparent to others, (2) there must be some variability in the purchase of the brand in that some consumers should have the resources to consume it whereas others do not, and (3) the brand must have personalizability in that it represents a stereotypical image of the average user. Based on the three characteristics of value-expressive products, Armstrong (2007) suggested that sport teams hold each of the characteristics needed to be a 
value-expressive product. First, sport spectating is an apparent social activity. This assertion could be further argued in terms of the BIRGing tendency of sport fans that sport consumers tend to position themselves favorably in the eyes of others by making indirect positive associations with favorably evaluated stimuli, such as sport teams (Cialdini, Borden, Thorne, Walker, Freeman, \& Sloan, 1976). Secondly, prices of tickets for games in conjunction with price segmentation of seat location affects consumers' ability to attend, thereby contributing to the variability in spectators' attendance. Finally, sport teams often represent distinctive brands of a sport product category based on their promotional activities, their playing styles, the personality of the players, and their logos or slogans.

Similar to the argument of the contingency approach to advertising, the FCB grid model developed by an advertising agency, Foote, Cone, and Belding also suggested that an affective advertising strategy that appeals to consumers' 'emotionality' is more effective for high involvement/feeling products, such as sports cars, jewelry, and fashion clothing, whereas an informative advertising strategy that appeals to consumers' 'rationality' is more effective for high involvement/thinking products, such as new cars, house, and furnishings (Lepkowska-White, Brashear, \& Weinberger, 2003; Vaughan, 1980). Considering the hedonic, affective, and symbolic nature of sport team consumption and the high importance of the sport team to sport consumers described earlier (Armstrong, 2007; Johar \& Sirgy, 1991; Vaughan, 1980), in this study, it is reasonable to expect that emotional advertising will be more effective for sport teams than rational advertising.

In addition to the relative effectiveness of emotional and rational appeals, there has been another view shared by researchers that emotional and rational appeals are not mutually exclusive (Pechman \& Stewart, 1989; Puto \& Wells, 1984). Emotional appeal ads may have rational appeal components while rational appeal ads can have emotional appeal components. In practice, many advertisers tend to use a combination of rational and emotional appeals (Albers-Miller \& Stafford, 1999). However, several studies on the effectiveness of the combined appeals suggested that rational and emotional appeals could interfere with each other (Armstrong, 2010; Elpers, Wedel, \& Pieters, 2003; Mehta \& Purvis, 2006; Stewart \& Furse, 1986).

For example, Mehta and Purvis (2006) analyzed 80 automobile ads and found that ads using either a rational or emotional appeal led to better recall than ads using both types of appeals. Similarly, Armstrong (2010) found that recall for ads that used either a rational or emotional appeal was 1.24 times better than ads that mixed them on the basis of an analysis of 50 pairs of print ads. Thus, it is reasonable to expect that both emotional and rational advertising will be more effective for sport teams than combination advertising.

\section{Research Hypotheses}

Although the definition of the term 'fanship' varies across sport marketing scholars, in general, they agree that fanship represents the psychological connection between sport fans and sport teams and the tendency to experience the teams' destiny as their own (Ashforth \& Mael, 1989; Funk \& James, 2001). Regarding its effect on sport consumer behavior, fanship has been researched as a vital determinant of various sport consumer behaviors such as BIRGing or CORFing (Wann \& Branscombe, 1990), game attendance (Fisher \& Wakefield, 1998), brand attitude (Bauer, Stokburger-Sauer, \& Exler, 2008), and team-related merchandise consumption (Lee \& Chalip, 2016). As identified above, since fanship has an impact on a variety of sport consumer behaviors, the focus in this study is only on the effect of types of advertising appeals on sport consumer behavior by controlling the effect of fanship as a covariate.

Based on the contingency approach, the FCB model, and Armstrong's (2007) work with acknowledging the potential of the effect of fanship, we propose three hypotheses:

H1: Sport consumers respond more positively towards emotional advertising than to rational advertising when controlling the effect of fanship.

$\mathrm{H} 2$ : Sport consumers respond more positively towards emotional advertising than to com bination advertising when controlling the effect of fanship.

H3: Sport consumers respond more positively towards rational advertising than to combi nation advertising when controlling the effect of fanship.

\section{Method}

\section{Research Design}

To test the relative effectiveness of emotional, rational, and combination advertising appeals on sport consumer behaviors, a 2 (emotion) $\times 2$ (cognition) incomplete factorial design was employed. The two levels of emotion were high and low. Likewise, the two levels of cognition were high and low. Since the cell described by low emotion and low cognition does not represent any one of the emotional, rational, and combination advertising, it was not presented in subsequent 
analyses. Therefore, three advertisements needed to be developed for each of the three experimental conditions, and thus, three advertisements were developed for the three experimental conditions.

\section{Stimuli}

The three advertisements were designed to stimulate respondents' emotion, or thinking, or both. Lee (2013) identified that tradition was a more emotionally appealing brand attribute whereas a stadium was a less emotionally (more cognitively) appealing brand attribute. Specifically, tradition was strongly associated with sport team-related emotions, such as 'proud,' 'passion,' and 'nostalgia' whereas a stadium was not (cf. Lee, 2013). Based on these findings, an emotional advertisement was created, which consisted of an image of a tradition specific to a team (the Texas Longhorns football team) and an associated advertising slogan that evokes respondents' emotion. Accordingly, the emotional advertisement for tradition included the image of Vince Young (the former quarterback of the Texas Longhorns football team) holding the Rose Bowl trophy (that can evoke a feeling of history of success) with an emotion-evoking slogan, "Tradition of Excellence."

A stadium was deemed to be an appropriate brand association used in the advertisement based on a rational appeal as the utilitarian value of a stadium (i.e. service quality - see Lee, Kim, Ko, \& Sagas, 2011) has a strong effect on people's decision to attend a game. The rational advertisement for stadium contained an image of the Texas Longhorns football stadium with a description of the features of the upgraded facility. The description of the features of the Longhorns football stadium was designed to stimulate respondents' cognitive thinking.

Since combination advertisements are advertising appeals that combine emotional and rational contents, the study used the same emotional advertisement described above, but added the information about other past national championships in the advertisement. Therefore, the combination advertisement included both emotional content (the same ad used for the emotional ad) and rational content (a description of other past national championships) as a rational input. The same format was used as in the emotional advertisement, and the information about other past national championships was added to appeal to respondents' thinking. In order to test for the correct reasoning of the authors, a manipulation check was conducted to examine if the advertisements were indeed perceived as such.

\section{Sample and Procedure}

A total of 324 participants with 108 participants for each of the three advertisements was recruited, from undergraduate classes at The University of Texas at Austin. The use of a student sample was regarded as an appropriate way in that they are not only a captive, easily reached audience, but also represent a key group of sport consumers (Ross, James, \& Vargas, 2006). The sample of 108 for each advertisement exceeded a large sample size $(n=100)$ per group in experimental design (cf. Stevens, 2007). In order to minimize the effect of gender difference, the gender ratio of each advertisement was the same (males $=54$ and females $=$ 54). The age of participants ranged from 18 to 43 years $(M=21.4)$. Along with receiving the survey questionnaires, each participant was assigned randomly to
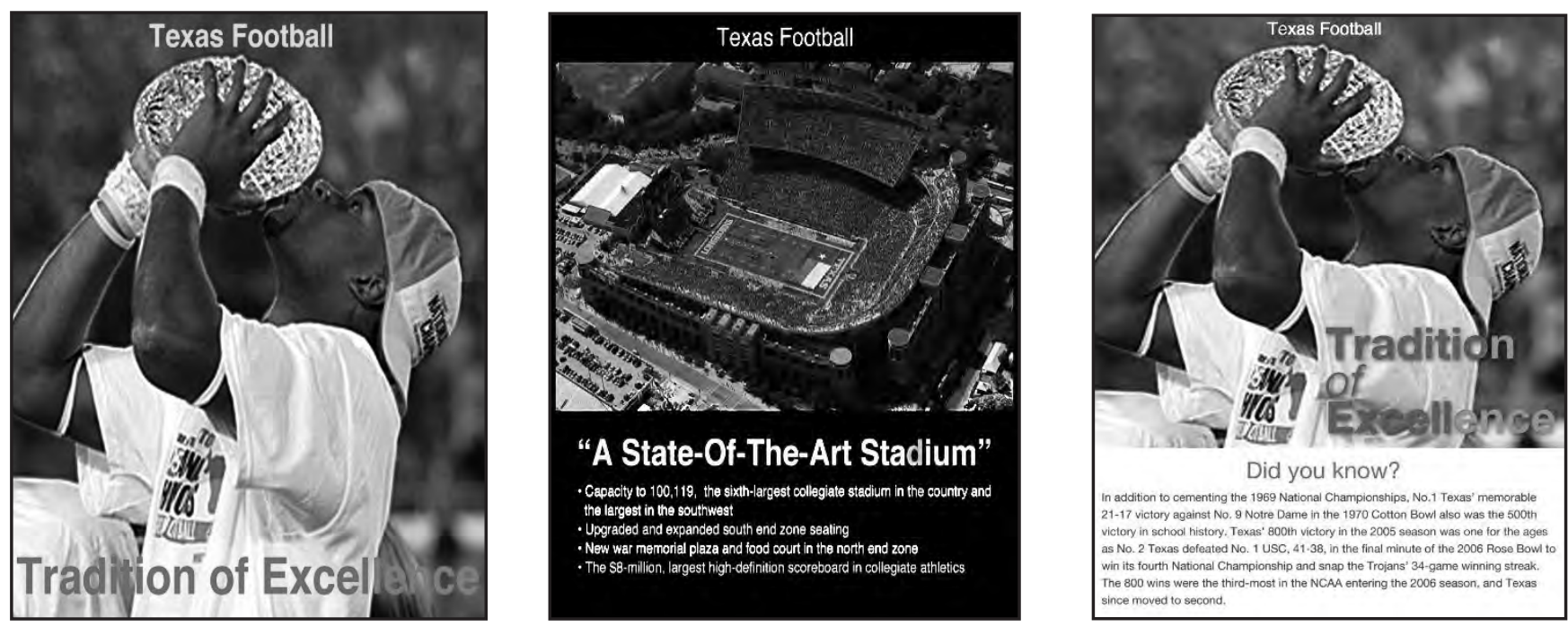

Figure 1. Emotional, Rational, and Combination Advertising 
one of the three experimental conditions (one of the three advertisements). Participants were first asked to carefully read an advertisement, and then were asked to provide answers to each question on the basis of the advertisement. The three advertisements are presented in Figure 1.

\section{Measure}

After exposure to the advertisements, participants were asked to indicate whether they perceived the ad to be emotional or rational, as a manipulation check to the research design. The manipulation check was conducted using Ruiz and Sicilia's (2004) two items: "The advertisement is emotional" and "The advertisement is informational." The two manipulation check items were assessed with a 7-point Likert scale ranging from 1 (strongly disagree) to 7 (strongly disagree). After completing the check, their attitudes toward the advertisements, attitudes toward the Longhorns football team, purchase intention, merchandise consumption, and fanship were measured. The rationale for choosing attitudes toward the ad $\left(\mathrm{A}_{\mathrm{ad}}\right)$, brand attribute $\left(\mathrm{A}_{\text {brand }}\right)$, purchase intention (PI), and merchandise consumption (MC) as the dependent variables for this study was that these are the widely used constructs to test the effectiveness of a variety of promotion strategies including advertising strategies across various academic disciplines, such as marketing, advertising, and sport consumer behavior (Milne \& McDonald, 1999; Yoo \& MacInnis, 2005).

$\mathrm{A}_{\mathrm{ad}}$ and $\mathrm{A}_{\text {brand }}$ were measured using Ang and Lim's (2006) 7-point semantic-differential items: not appealing/very appealing, not interesting/very interesting, dislike/like, and bad/good. PI was measured with an adaptation of Lee and Chalip's (2016) item: "How likely do you think it is that you would attend the Texas Longhorns football team's game(s) in the future?" with a 7-point Likert scale ranging from 1 (not at all) to 7 (very likely). $\mathrm{MC}$ was measured with an adaptation of Lee and Chalip's (2016) item: "How likely do you think it is that you would purchase the Texas Longhorns football team's merchandise?" with a 7-point Likert scale ranging from 1 (not at all) to 7 (very likely).
The measure for fanship was adopted from Trail and James' (2001) scale and was slightly changed to fit in the context of Longhorns football: "I consider myself to be a "real" fan of the Longhorns football team" "I would experience a loss if I had to stop being a fan of the Longhorns football team" and "Being a fan of the Longhorns football team is very important to me." All three items were measured with a 7-point Likert scale ranging from 1 (strongly disagree) to 7 (strongly agree). Demographic questions such as gender and age were included in the survey.

\section{Data Analysis}

To test the relative effectiveness of types of advertising appeals on consumer behaviors, multiple ANCOVAs with three experimental conditions (emotional ad: high emotion/low cognition vs. rational ad: low emotion/high cognition vs. combination ad: high emotion/high cognition) were conducted for the four dependent variables: $A_{a d}, A_{b r a n d}$, PI, and MC. Fanship was included as a covariate in order to control for a pre-existing characteristic that has been shown to affect the four dependent variables (Bauer et al., 2008; Fisher \& Wakefield, 1998; Lee \& Chalip, 2016; Wann \& Branscombe, 1990).

\section{Results}

\section{Manipulation Check}

To test the manipulation effects of three types of advertising appeals (emotional, rational, and combination advertising), respondents were asked to rate the extent to which the given advertisements were emotional or informational. As shown in Table 1, t-test analyses indicated that all three advertisements satisfied the manipulation check. Respondents' perceptions about manipulations in emotion and information for the three advertisements were effective. All mean scores for three advertisements differed significantly with respect to the medium point (4) of the scale (cf. Ruiz \& Sicilia, 2004).

Table 1. Results of Manipulation Check

\begin{tabular}{l|c|c}
\hline Ad type & Emotion transmission & Information transmission \\
\hline Emotional ad & $5.58^{\star}$ & $2.94^{\star}$ \\
\hline Rational ad & $2.80^{\star}$ & $5.77^{\star}$ \\
\hline Combination ad & $5.60^{\star}$ & $5.70^{\star}$ \\
\hline
\end{tabular}

Asterisk represents significance of difference with respect to the medium point of the scale (4). ${ }^{*} p<.01$. 
Table 2. Reliability of Dependent Measures and Covariate

\begin{tabular}{l|l|l}
\hline Ad type & DVs and Covariate & Cronbach's $\alpha$ \\
\hline Emotional ad & Attitude toward the ad & .898 \\
& Attitude toward the brand & .919 \\
& Fanship & .819 \\
\hline Rational ad & Attitude toward the ad & .918 \\
& Attitude toward the brand & .926 \\
& Fanship & .876 \\
\hline Combination ad & Attitude toward the ad & .915 \\
& Attitude toward the brand & .841 \\
& Fanship & .927 \\
\hline
\end{tabular}

\section{Reliability}

Cronbach's alphas were calculated to check for the internal consistency of the two dependent variables $\left(\mathrm{A}_{\mathrm{ad}}\right.$ and $A_{\text {brand }}$ ) and covariate (fanship) for each of the three advertisements. Since PI and MC were measured using a single item, their reliability was not tested. As shown in Table 2, all Cronbach's alphas for the three scales across the three advertising settings were higher than the cut-off of .80 (cf. Lance, Butts, \& Michels, 2006). Therefore, all three scales were deemed to be reliable.

\section{Comparing the Effects of Three Types of Advertising Appeals}

To compare the effectiveness of emotional, rational, and combinational ads on consumer behavior, multiple ANCOVAs with three experimental conditions were performed for the four dependent variables: $A_{\text {ad, }}, A_{\text {brand, }}$ PI, and MC. Fanship was the covariate. As a result of the ANCOVAs, univariate tests showed the main effects of ad type on the four dependent variables: for $\mathrm{A}_{\mathrm{ad}}, F(2,320)=21.078, p=.001$; for $\mathrm{A}_{\text {brand, }}$, $F(2,320)=7.922, p=.001$; for PI, $F(2,320)=6.694, p$ $=.001$; for MC, $F(2,320)=7.517, p=.001$. The covariate, fanship, was significant for all four dependent measures: for $\mathrm{A}_{\mathrm{ad}}, F(1,320)=6.646, p=.010$; for $\mathrm{A}_{\text {brand, }}$, $F(1,320)=142.173, p=.001$; for PI, $F(1,320)=83.268$, $p=.001$; for MC, $F(1,320)=50.818, p=.001$. Means of the four dependent variables, after controlling for the effect of fanship, are shown in Table 3.

However, because ad type as an independent variable has three categories (emotional, rational, and combination ads), pairwise comparisons tests were conducted to examine whether there are significant differences in the effects of the three advertisements on the four dependent variables. As shown in Table 4, for $A_{\text {ad, }}$, the emotional ad was greater than both the combination and rational ads while the combination ad was greater than the rational ad. For Abrand, PI, and MC, the emotional ad was greater than both the rational

Table 3. Estimated Marginal Means of DVs after Controlling for the Effect of Fanship

\begin{tabular}{l|c|c|c}
\hline DVs & Ad type & Mean & S.E. \\
\hline \multirow{2}{*}{ Ad attitude } & Emotional & 5.52 & .13 \\
& Rational & 4.39 & .12 \\
& Combination & 5.05 & .12 \\
\hline Brand attitude & Emotional & 6.07 & .09 \\
& Rational & 5.56 & .09 \\
& Combination & 5.79 & .09 \\
\hline Purchase intention & Emotional & 6.45 & .12 \\
& Rational & 5.88 & .12 \\
& Combination & 5.90 & .12 \\
\hline Mechandise consumption & Emotional & 6.25 & .14 \\
& Rational & 5.51 & .13 \\
& Combination & 5.82 & .14 \\
\hline
\end{tabular}


Table 4. Pairwise Comparisons Tests for Three Advertisements

\begin{tabular}{|c|c|c|c|c|c|}
\hline DVs & (1) Ad type & (2) Ad tpe & $(1)-(2)=$ Mean Diff. & $p$-value & $\begin{array}{l}\text { Differences between three ads at the } \\
\qquad p=.05 \text { level }\end{array}$ \\
\hline \multirow[t]{3}{*}{ Ad attitude } & Emotional & Rational & 1.13 & .001 & \multirow{3}{*}{$\begin{array}{c}\text { Emotional }>\text { Combination }> \\
\text { Rational }\end{array}$} \\
\hline & Emotional & Combination & .47 & .009 & \\
\hline & Combination & Rational & .66 & .001 & \\
\hline \multirow[t]{3}{*}{ Brand attitude } & Emotional & Rational & .51 & .001 & \multirow{3}{*}{$\begin{array}{l}\text { Emotional > Rational and } \\
\text { Combination }\end{array}$} \\
\hline & Emotional & Combination & .28 & .032 & \\
\hline & Combination & Rational & .23 & .070 & \\
\hline \multirow[t]{3}{*}{ Purchase intention } & Emotional & Rational & .57 & .001 & \multirow{3}{*}{$\begin{array}{l}\text { Emotional }>\text { Rational and } \\
\text { Combination }\end{array}$} \\
\hline & Emotional & Combination & .55 & .002 & \\
\hline & Combination & Rational & .02 & .920 & \\
\hline \multirow[t]{3}{*}{ Mechandise consumption } & Emotional & Rational & .74 & .001 & \multirow{3}{*}{$\begin{array}{c}\text { Emotional > Rational and } \\
\text { Combination }\end{array}$} \\
\hline & Emotional & Combination & .43 & .029 & \\
\hline & Combination & Rational & .31 & .097 & \\
\hline
\end{tabular}

and combination ads while there was no significant difference between the rational and combination ads. Consequently, $\mathrm{H} 1$ and $\mathrm{H} 2$ were accepted whereas $\mathrm{H} 3$ was rejected. In summary, emotional advertising was more effective for the four consumer behaviors (attitude toward the ad, brand attitude, purchase intention, and merchandise consumption) while combination advertising was more effective for attitude toward the ad than rational advertising.

\section{Discussion}

This study provided empirical evidence of the relative supremacy of emotional advertising over its counterpart, rational advertising, in a collegiate sport team setting. Specifically, the authors found that the effect of emotional advertising appeal on sport consumer behavior in college students was greater than that of rational advertising appeal, implying that at least college students tend to be driven more by emotions in their sport team consumption (as symbolic consumption) than rational considerations. This finding is in line with the argument of the contingency approach and the FCB model suggesting that emotional advertising is more effective for symbolic products (e.g., Armstrong, 2007; Holbrook \& O'Shaughnessy, 1984; Johar \& Sirgy, 1991; Vaughan, 1980). As symbolic products are primarily consumed for affective and self-expressive purposes (Mano \& Oliver, 1993; Vaughan, 1980), it is not surprising that emotional advertising that appeals to respondents' emotional arousal and self-expressive needs had a greater effect on $\mathrm{A}_{\text {ad, }}, \mathrm{A}_{\text {brand, }} \mathrm{PI}$, and $\mathrm{MC}$ than rational advertising.
In addition, this finding is in line with the assertion of the recent neuroscience approach in advertising that emotions (rather than cognition) play a more significant role in the advertising process (Ambler \& Bume, 1999; Du Plessis, 2005; Hall, 2002). In the realm of advertising, the traditional AIDA (Attention-Interest-Desire-Action) model or hierarchy of effects model has been the foremost model for quite some time. According to the AIDA approach, desire (defined in the model as similar to emotions) took place only after consumers engaged in cognitive processing (interest). In this model, the role of emotions is limited in the sense that it can generate behavior (action) only on the basis of how cognition works. However, neuroscience has found a scientific basis for why the emotional content of advertising is more influential than any rational information. According to LeDoux (1996), the direct link between the thalamus and the emotional brain (amygdala) enables the brain to respond emotionally, before conscious awareness of stimuli. Furthermore, Damasio $(1994,1999)$ suggested that when emotion and cognition enter into conflict, emotions win. A neurologist Calne (2000) clearly states the essential role of emotion in decision-making, "The essential difference between emotion and reason is that emotion leads to action while reason leads to conclusions" (p. 14). In short, the evidence of the dominant effectiveness of emotional advertising over rational advertising in predicting college students' consumption behaviors identified from this study suggests that the traditional AIDA model might need to be refined in order to be 
applicable to the context of symbolic consumption where sport team brands are consumed.

In contrast to some of the literature (e.g., Armstrong, 2010; Mehta \& Purvis, 2006), the results of this study suggested that the effect of combination advertising on college students' consumption behavior was at least equal to or greater than that of rational advertising whereas as expected, its effect was less than the effect of emotional advertising. These findings are in part contrary to prior works suggesting that either a rational or emotional appeal is more effective for consumer responses than a combination appeal because the emotional and rational contents of combination advertising can interfere with each other (e.g., Armstrong, 2010; Elpers et al., 2003; Mehta \& Purvis, 2006; Stewart \& Furse, 1986). This unexpected outcome may be accounted for by the symbolic nature prevailing in sport team consumption. Previous work in sport brand literature suggested that sport team consumption is symbolic in nature (Bauer et al., 2008; Gladden \& Funk, 2002). This perspective posits that sport consumers tend to consume their team due to symbolic reasons rather than functional reasons, which can meet sport consumers' underlying needs such as self-enhancement and self-expression. Of course, as confirmed in this study, emotional advertising is the most effective to satisfy these symbolic needs of sport consumers. However, the emotional content does not diminish when combined with rational information. When sport consumers are exposed to combination advertising, its emotional component might be more important to them than its rational component, but the insertion of rational elements might not be detrimental to the effectiveness of the advertisement.

\section{Managerial Implications}

In today's world, people digest more information than ever before in history, and this has placed a burden on our capacity to process all that information. It is estimated that each individual receives anywhere in between 3,000 to 20,000 commercial messages a day, yet only an average of 153 of those messages hold our attention for more than a couple of seconds ("New Research," 2014). Based on the assumption that cognitive processing takes more than a couple of seconds, we could argue that with most of the commercial messages we are confronted with we only connect to at an emotional level. Our findings suggest that while sport marketers could add some cognitive information to their advertisements, they are well advised to put emotion at the center of their advertising. Existing sport management research offers several pathways to insert emotions in sport advertising. First, sport marketers can insert certain positive emotions, such as connectedness, elation, and competitiveness, directly into their messaging as they tend to positively affect sport consumer behavior (cf. Lee, Kim, \& Heere, in press). Second, Lee, Lee, Seo, and Green (2012) and Lee, Heere, and Chung (2013) proposed that our senses (sight, sound, touch, smell, and taste) have a strong impact on our emotions and provide a strong source for emotional branding, as they provide other outlets for emotional advertising beyond visual aspects.

\section{Limitations and Future Research}

Although the findings provide sport marketers with some insight into how they can design advertising campaigns for their fans, the limitations of the study need to be taken into account when interpreting the data. Since the authors tested the effectiveness of emotional, rational, and combination advertising only in a United States college football setting (i.e., the Texas Longhorns football team), the generalization of the data to other contexts or cultures might be limited. While the authors do not believe that the symbolism associated with sports is limited to this setting or the United States, this assertion does warrant further investigation. Accordingly, future research should seek to test and confirm the relative effectiveness of the three advertising appeals identified in this study across different contexts (e.g., sports, levels of sport, other college football teams, different age groups). Additionally, the two primers used to test for emotion and rationality (i.e., tradition and stadium) might each be accompanied by certain biases within their own setting, and future research should insert other brand associations that could further validate the emotional/ rational categorization.

\section{Conclusion}

This study is a first step in exploring the relative effectiveness of emotional, rational, and combination advertising in a sport advertising setting and demonstrated that emotional advertising that evokes emotions associated with sport teams is a vital means to foster sport consumers' approach behavior. The message from this finding is clear. As emotional advertising more effectively guides sport consumer behavior than rational and combination advertising, marketers should develop specific advertising strategies that are able to evoke or appeal to sport consumers' emotions.

\section{References}

Aaker, D. A., Batra, R., \& Myers, J. G. (1992). Advertising management (4th ed.). Englewood Cliffs, NJ: Prentice-Hall.

Aaker, D. A, \& Norris, D. (1982). Characteristics of TV commercials perceived as informative. Journal of Advertising Research, 22, 61-70. 
Abernethy, A., \& Butler, D. D. (1992). Advertising information: Services vs products. Journal of Retailing, 68(4), 398-419.

Albers-Miller, N. D., \& Stafford, M. R. (1999). An international analysis of emotional and rational appeals in services vs goods advertising. Journal of Consumer Marketing, 16(1), 42-57.

Ambler, T., \& Burne, T. (1999). The impact of affect on memory of advertising. Journal of Advertising Research, 39, 25-34.

Ang, S. H., \& Lim, E. A. C. (2006). The influence of metaphors and product type on brand personality perceptions and attitudes. Journal of Advertising, 35, 39-53.

Armstrong, J. S. (2010). Persuasive advertising. London: Palgrave Macmillan.

Armstrong, K. L. (2007). Self, situations, and sport consumption: An exploratory study of symbolic interactionism. Journal of Sport Behavior, 30(2), 111-129.

Ashforth, B. E., \& Mael, F. (1989). Social identity theory and the organization. Academy of Management Review, 14(1), 20-30.

Batra, R., \& Ray, M. L. (1985). How advertising works at contact. In L. F. Alwitt, \& A. A. Mitchell (Eds.), Psychological processes and advertising effects: Theory, research and application (pp. 13-44). Hillsdale, NJ: Lawrence Erlbaum Associates.

Bauer, H. H., Stokburger-Sauer, N. E., \& Exler, S. (2008). Brand image and fan loyalty in professional team sport: A refined model and empirical assessment. Journal of Sport Management, 22, 205-226.

Belch, G. E., \& Belch, M. A. (2015). Advertising: An integrated marketing communication perspective (10th ed.). New York: McGraw-Hill Education.

Bettman, J. R. (1979). An information processing theory of consumer choice. Reading, MA: Addison-Wesley.

Brady, E., Berkowitz, S., \& Upton, J. (2016, April 17). Can college athletics continue to spend like this? USA Today. Retrieved from https://www.usatoday.com/story/sports/ college/2016/04/17/ncaa-football-basketball-power-five-revenue-expenses/83035862/

Calder, B. J., \& Gruder, C. L. (1989). Emotional advertising appeals. In P. Cafferata, \& A. M. Tybout (Eds.), Cognitive and affective responses to advertising (pp. 278-285). Lexington, MA: Lexington Books.

Calne, D. (2000). Within reason: Rationality and human behavior. New York: Vintage Books.

Cialdini, R. B., Borden, R. J., Thorne, A., Walker, M. R., Freeman, S., \& Sloan, L. R. (1976). Basking in reflected glory: Three (football) field studies. Journal of Personality and Social Psychology, 34(3), 366-375.

Copeland, M. T. (1924). Principles of merchandising. New York: Arno Press.

Cornelis, E., Adams, L., \& Cauberghe, V. (2012). The effectiveness of regulatory (in) congruent ads: The moderating role of an ad's rational versus emotional tone. International Journal of Advertising, 31(2), 397-420.

Cutler, B. D., \& Javalgi, R. G. (1993). Analysis of print ad features: Services versus products. Journal of Advertising Research, 33(2), 62-69.

Damasio, A. R. (1994). Descartes' error. New York: Avon Books.

Damasio, A. R. (1999). The feeling of what happens: Body and emotion in the making of consciousness. San Diego, CA: Harvest Books.

Du Plessis, E. (2005). The advertised mind: Groundbreaking insights into how our brains respond to advertising. London: Millward Brown.

Elpers, J. W., Wedel, M., \& Pieters, R. G. M. (2003). Why do consumers stop viewing television commercials? Two experiments on the influence of moment-to-moment entertainment and information value. Journal of Marketing Research, 40, 437-453.
Fisher, R. J., \& Wakefield, K. (1998). Factors leading to group identification: A field study of winners and losers. Psychology \& Marketing, 15, 23-40.

Funk, D. C. \& James, J. D. (2001). The Psychological Continuum Model: A conceptual framework for understanding an individual's psychological connection to sport. Sport Management Review, 4(2), 119-150.

Gladden, J. M., \& Funk, D. C. (2002). Developing an understanding of brand associations in team sport: Empirical evidence from consumers of professional sport. Journal of Sport Management, 16, 54-81.

Goldberg, M. E, \& Gorn, G. J. (1987). Happy and sad TV programs: How they affect reactions to commercials. Journal of Consumer Research, 14, 387-403.

Golden, L., \& Johnson, K. A. (1983). The impact of sensory preferences and thinking vs. feeling appeals on advertising effectiveness. In R. P. Bagozzi, \& A. M. Tybout (Eds.), Advances in consumer research (pp. 203-208). Ann Arbor, MI: Association for Consumer Research.

Gopinath, S., Thomas, J. S., \& Krishnamurthi, L. (2014). Investigating the relationship between the content of online word of mouth, advertising, and brand performance. Marketing Science, 33(2), 241-258.

Hall, B. E. (2002). A new model for measuring advertising effectiveness. Journal of Advertising Research, 42, 23-31.

Hirschman, E. C., \& Holbrook, M. B. (1982). Hedonic consumption: Emerging concepts, methods, and propositions. Journal of Marketing, 46, 92-101.

Holbrook, M. B., \& Hirschman, E. C. (1982). The experiential aspects of consumption: Consumer fantasies, feelings, and fun. Journal of Consumer Research, 9, 132-140.

Holbrook, M. B., \& O'Shaughnessy, J. (1984). The role of emotion in advertising. Psychology \& Marketing, 1, 45-64.

Hopkinson, G. C., \&Pujari, D. (1999). A factor analytic study of the sources of meaning in hedonic consumption. European Journal of Marketing, 33(3/4), 273-290.

Huertas, M. K. Z., \& Campomar, M. C. (2009). Rational and emotional appeals in advertising of prescription medicines: Study of a slimming drug in Brazil. Innovative Marketing, 5(4), 80-88.

Johar, J. S., \& Sirgy, M. J. (1991). Value-expressive versus utilitarian advertising appeals: When and why to use which appeal. Journal of advertising, 20(3), 23-33.

Kotler, P., \& Armstrong, G. (2009). Principles of marketing (13th ed.). Englewood Cliffs, NJ: Prentice-Hall.

LaBand, D. N., Pickett, G. M., \& Grove, S. J. (1992). An empirical examination of the informational content of services advertisements. In R. P. Leone, \& V. Kumar (Eds.), Enhancing knowledge development in marketing (pp. 166-167). Chicago, IL: American Marketing Association.

Lance, C. E., Butts, M. M., \& Michels, L. C. (2006). The sources of four commonly reported cutoff criteria: What did they really say?" Organizational Research Methods, 9(April), 202-220.

LeDoux, J. E. (1996). The emotional brain: The mysterious underpinnings of emotional life. New York: Simon and Schuster.

Lee, J. K., Kim, H. D., Ko, Y. J., \& Sagas, M. (2011). The influence of service quality on satisfaction and intention: A gender segmentation strategy. Sport Management Review, 14(1), 54-63.

Lee, S. (2013). Identifying emotions associated with sport team brands and testing its impact on sport consumer behavior in the advertising setting (Unpublished doctoral dissertation). The University of Texas at Austin, Austin, TX.

Lee, S., \& Chalip, L. (2016). Understanding factors affecting the choice of a sport licensed product over its unlicensed alternative. Korean Journal of Sport Management, 21(2), 35-54. 
Lee, S., Heere, B., \& Chung, K. S. (2013). Which senses matter more? The impact of our senses on team identity and team loyalty. Sport Marketing Quarterly, 22(4), 203-213.

Lee, S., Kim, Y., and Heere, B. (in press). Sport team emotion: Conceptualization, scale development and validation. Sport Marketing Review.

Lee, S., Lee, H. J., Seo, W. J., \& Green, B. C. (2012). A new approach to stadium experience: The dynamics of the sensoryscape, social interaction, and sense of home. Journal of Sport Management, 26, 490-505.

Lepkowska-White, E., Brashear, T. G., \& Weinberger, M. G. (2003). A test of ad appeal effectiveness in Poland and The United States-the interplay of appeal, product, and culture. Journal of Advertising, 32(3), 57-66.

Lwin, M., \& Phau, I. (2013). Effective advertising appeals for websites of small boutique hotels. Journal of Research in Interactive Marketing, 7(1), 18-32.

Lwin, M., Phau, I., Huang, Y. A., \& Lim, A. (2014). Examining the moderating role of rational-versus emotional-focused websites: The case of boutique hotels. Journal of Vacation Marketing, 20(2), 95-109.

Mano, H., \& Oliver, R. L. (1993). Assessing the dimensionality and structure of the consumption experience: Evaluation, feeling, and satisfaction. Journal of Consumer Research, 20, 451-466.

Mehta, A., \& Purvis, S. C. (2006). Reconsidering recall and emotion in advertising. Journal of Advertising Research, 46(1), 49-56.

Milne, G. R., \& McDonald, M. A. (1999). Sport marketing: Managing the exchange process. Sudbury, MA: Jones \& Bartlett Learning.

Mowen, J. C. (1995). Consumer behavior (4th ed.). Englewood Cliffs, NJ: Prentice-Hall.

New research sheds light on daily ad exposures. (2014, September 29). SJ Insights. Retrieved from https://sjinsights.net/2014/09/29/ new-research-sheds-light-on-daily-ad-exposures/

Page, T. J., Thorson, E., \& Heide, M. P. (1990). The memory impact of commercials varying in emotional appeal and product involvement. In S. J. Agres, J. A. Edell, \& T. M. Dubitsky (Eds.), Emotion in advertising (pp. 255-268). New York: Quorum Books.

Panda, T. K., Panda, T. K., \& Mishra, K. (2013). Does emotional appeal work in advertising? The rationality behind using emotional appeal to create favorable brand attitude. IUP Journal of Brand Management, 10(2), 7-23.

Pechmann, C., \& Stewart, D. W. (1989). The multidimensionality of persuasive communications: Theoretical and empirical foundations. In P. Cafferata, \& A. M. Tybout (Eds.), Cognitive and affective responses to advertising (pp. 31-65). Lexington, MA: Lexington Books.

Puto, C. P., \& Wells, W. D. (1984). Informational and transformational advertising: The differential effects of time. Advances in Consumer Research 11, 638-643.

Ross, S. D., James, J. D., \& Vargas, P. (2006). Development of a scale to measure team brand associations in professional sport. Journal of Sport Management, 20(2), 260-279.

Ruiz, S., \& Sicilia, M. (2004). The impact of cognitive and/or affective processing styles on consumer response to advertising appeals. Journal of Business Research, 57(6), 657-664.

Sewall, M. A., \& Sarel, D. (1986). Characteristics of radio commercials and their recall effectiveness. Journal of Marketing, 50, 52-60.

Shank, M. D., \& Lyberger, M. R. (2015). Sports marketing: A strategic perspective (5th ed.). New York: Routledge.

Shavitt, S. (1990). The role of attitude objects in attitude functions. Journal of Experimental Social Psychology, 26, 124-148.
Shavitt, S. (1992). Evidence for predicting the effectiveness of value-expressive versus utilitarian appeals: A reply to Johar and Sirgy. Journal of Advertising, 21, 47-51.

Sheth, J. N. (1973). Model of industrial buyer behavior. Journal of Marketing, 37, 50-56.

Stevens, J. P. (2007). Intermediate statistics: A modern approach (3rd ed.). New York: Routledge.

Stewart, D. W., \& Furse, D. H. (1986). Effective television advertising: A study of 1000 commercials. Lexington, MA: Lexington Books.

Trail, G. T., \& James, J. D. (2001). The motivation scale for sport consumption: Assessment of the scale's psychometric properties. Journal of Sport Behavior, 24, 108-127.

Um, N. H. (2008). Revisit elaboration likelihood model: How advertising appeals work on attitudinal and behavioral brand loyalty centering around low vs. high-involvement product. European Journal of Social Sciences, 7(1), 126-139.

Vaughn. R. (1980). How advertising works: A planning model. Journal of Advertising Research, 20(5), 27-33.

Wann, D. L., \& Branscombe, N. R. (1990). Die-hard and fair-weather fans: Effects of identification on BIRGing and CORFing tendencies. Journal of Sport and Social Issues, 14, 103-117.

Yoo, C., \& MacInnis, D. (2005). The brand attitude formation process of emotional and informational ads. Journal of Business Research, 58(10), 1397-1406.

Zinkhan, G. M., Johnson, M., \& Zinkhan, F. C. (1992). Differences between product and services television commercials. Journal of Services Marketing, 6, 59-66.

Zhang, H., Sun, J., Liu, F., \& Knight, J. G. (2014). Be rational or be emotional: Advertising appeals, service types and consumer responses. European Journal of Marketing, 48(11/12), 2105-2126. 